\title{
Design of Power Distribution on Operator Control Unit (OCU) Rhino Robot
}

\author{
Ahmad Nur Riza ${ }^{1}$, Imam Arifin ${ }^{1}$, Mahardhika Pratama², and Lidikri Mohammad Fasha ${ }^{3}$
}

\begin{abstract}
OCU Rhino Robot contains from some components with voltage supply requirement was different. Design power distribution was required in this system to provide voltage what correspond with requirement. Using battery what it installed in $O C U$, so need to display indicator for knowing battery condition. For doing charging process, previously batter must to remove battery from device. So need to made charging system concept what it can make it easier user. Result from this design, knowing that device can operated about 4 hours and 44 minutes. Obtained rating $\mathrm{SoC}$ value in $0-107 \%$ with voltage $16.35 \mathrm{VDC}$ when battery was full and 11.9VDC when battery was empty. The value could use as reference at developing charging system on $O C U$ in the next version.
\end{abstract}

Keywords-Power Distribution, OCU, Rhino Robot

\section{INTRODUCTION}

Along with growing technology, each human activities never release with robot help. In military sector robot has an important role, where can be used for help and protect soldier with doing any intelligence, surveillance, Explosive Ordnance Disposal (EOD) and logistic task [1].

PT. Bhimasena Research and Development were developing Rhino Robot that be used to EOD task. The robot work to come near and take items what considered was danger [2]. With the device expected can to reduce accident possibility were experienced by user. There are two part on the robot, it was chassis and arm. Each the part has own function, chassis be used for robot mobility and arm be used for take a desired object. Furthermore, on chassis be equipped with flipper, the function was for help robot so can through uneven field, like up and down stairs.

To control robot be used Operator Control Unit (OCU) [1] . The device composed from some load like LCD, and main controller where in this system be used Lattepanda. From each load has a requirement power supply so that work, so need to connect with source. On other side, in power transmission, loss and efficient energy became an often problem be noticed [3]. Through the process connected, need to source management to each load so power given corresponding with requirement. For manage, so need to did design power distribution.

\footnotetext{
${ }^{1}$ Ahmad Nur Riza and Imam Arifin are with Department of Automation Electrical Engineering, Institut Teknologi Sepuluh Nopember, Surabaya, 60111, Indonesia. E-mail: rizaahmadnur@gmail.com.

${ }^{2}$ Mahardhika Pratama is with School of Computer Science and Engineering, Nanyang Technologycal University (NTU).

${ }^{3}$ Ayyasy Az Zurqi is with Staff of PT Bhimasena Research and Development.
}

In this experiment, be made system what can be given power supply was corresponding with load requirements. Furthermore, be made additional system what it has relation with source so can to help easier operator when using device.

This paper contains from five section that explain about power distribution. First section discussion about background and purpose from research has been done. Then on the next section discuss about problem that were resolved in this research. Third section explained about design to resolve the problem. Then from design has been made, it tested and the result was analyzed. The last from this paper was conclusion from result of research.

\section{POWER DISTRIBUTION OCU}

\section{A. Power Distribution}

In the literature [4] was mentioned that DC distribution contains from source, conductor, and load. On this research, be used source from battery. For connect load with source can be used conductor, where on this system did source management early previously distributed to each load. Efficient and voltage disturbance became important aspect in design this system [3].

Battery on this system was installed in OCU, so difficult to know condition of it. From the problem so need to displayed condition of battery to panel of OCU especially battery capacity. Then to battery recharge need to remove battery previously, because charger was available require to charge battery without load was connected.

Furthermore, this system using smart battery, where it contains from two section. Each section has capacity 7.5Ah and voltage $15 \mathrm{VDC}$. In the battery has some data that can be accessed. To access the data communication was needed, where this system using System Management Bus (SMBus) Protocol to obtain the data. Problem from this research was address and command code on each section was same.

On this design, there are three things must be done, it was powering system, indicator system and charging system. Purpose from powering system was to divide supply from battery to each load that used. Indicator system be made to display condition that has relation with source. In the charging system be made concept to doing charging process that it easy without need remove battery previously.

\section{B. Constant Current Constant Voltage Methods}

In made charging system concept was used Constant Current Constant Voltage Methods (CCCV). This method was way that most way be used on practice, because that way was simple and easy to implements. This process was 
combination between constant current and constant voltage mode [5]. Therefore, this system guarantee fast charging process when battery can receive high current and battery polarity was limited at end of charging, so can to prevent cell failure [6].

Constant current was ability to variant voltage on electronic circuit for defending current in constant condition [7]. This mode work using the high internal resistance and load resistance was lower [8].

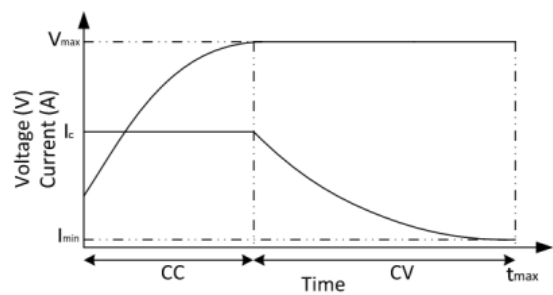

Figure 1. Graphic of Current and Voltage on CCCV Methods.

Constant voltage was reverse, it was ability to variant output current with purpose to defending voltage so it can constant [9]. Common source be used was battery and power supply[10].

From Figure 1 can be seen that charging process begin using constant current mode until battery voltage achieve the maximum value. Then will change to constant voltage mode, at the step battery has loaded $85 \%$ of total capacity. Furthermore, in this mode current charging always to monitor, the purpose was to define when charging process was terminated. Usually battery considered full when current charging decrease under $0.1 \mathrm{C}$ [11].

\section{DESIGN POWER DISTRIBUTION OCU}

On this system there are three part, it was powering system that function to doing dividing supply from battery to source. Then, indicator system that used to display conditions that has relation with source. And last was charging system to doing charging to battery.

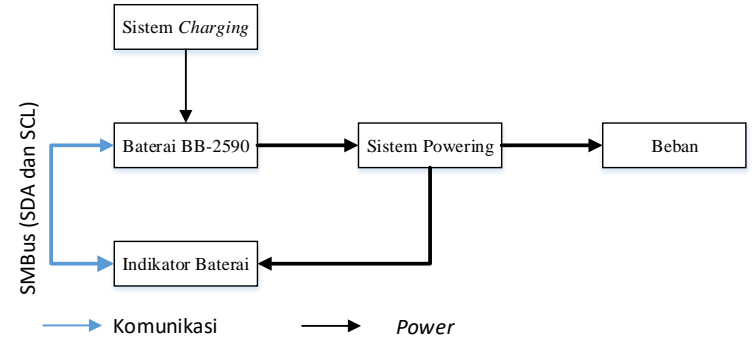

Figure 2. Power Distribution OCU Configuration.

On Figure 2 could see, before power from battery entry to load, processing done on powering system previously. There was voltage regulator inside. There was microcontroller inside battery indicator, it used to communicate with battery via SMBus. Doing communication to obtained data from battery and then displayed in led as indicator. Charging system that use in this system was charger from manufacturer battery, so to doing charging process, battery must be removed previously.

\section{A. Powering System}

On this step, doing source management from battery to load. On Figure 3 could be seen, that in this system have a three par, it was protection system, voltage regulator and switching. Furthermore, there was a keylock switch that used to break and connect battery to system.

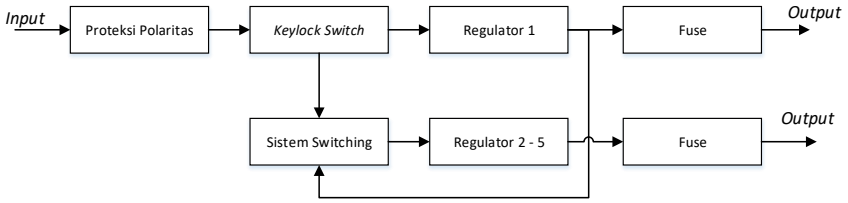

Figure 3. Block Diagram Powering System.

In this step done load grouping and voltage regulator, suitable with Table 1. Suitable with has explained on part voltage regulator, that on this system be used IC LM2596. But, for voltage regulator 1 be used other product, because on first load has a requirement output voltage with low noise and constant current.

TABLE 1.

GROUP OF LOAD AND VOLTAGE REGULATOR

\begin{tabular}{cccc}
\hline \hline No. & $\begin{array}{c}\text { Regulator } \\
\text { Ke- }\end{array}$ & $\begin{array}{c}\text { Output } \\
\text { Tegangan }\end{array}$ & Beban \\
\hline 1. & 1 & $5 \mathrm{~V}$ & Lattepanda \\
2. & 2 & $5 \mathrm{~V}$ & ATMEGA dan Board Push \\
3. & 3 & $12 \mathrm{~V}$ & Button \\
4. & 4 & $12 \mathrm{~V}$ & Board LED \\
5. & 5 & $12 \mathrm{~V}$ & LCD \\
6. & 6 & $5 \mathrm{~V}$ & Transmitter, Led \\
Emergency \\
\hline \hline
\end{tabular}

From Figure 4 could be see that to doing activation OCU process done with two step, it was rotate keylock switch to on position then to push power push button.

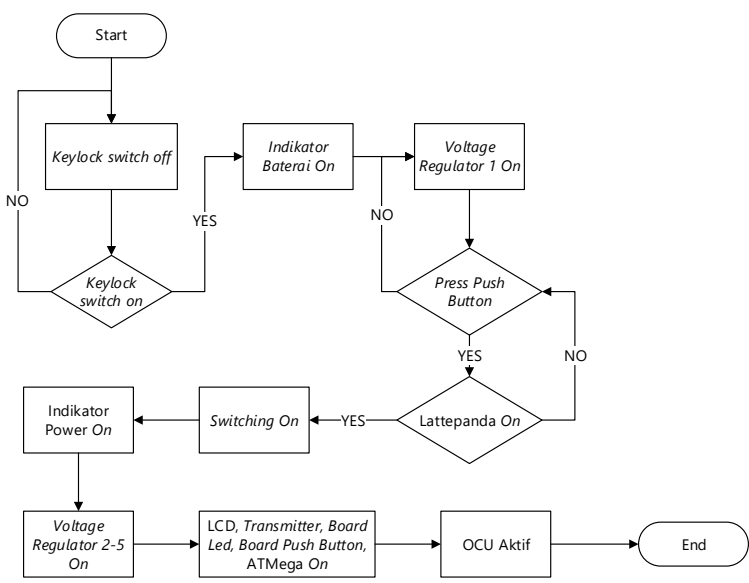

Figure 4. Activation OCU Flowchart.

\section{B. Indicator System}

There are two indicators was displayed on OCU panel, it was power and level battery indicator. Each indicator was displayed using led. Power indicator to purpose to knowing 
user that OCU active or off. Led will be active when power push button was pressed and will off when OCU off. Battery level indicator has a function to display remaining capacity battery. So user can to knowing when must be doing charging and can to predict how long device can be used. In this board have two part it was host system and voltage regulator. Indicator was displayed using 4 led that structured vertically on panel. There are three colors was used, it was red, yellow and 2 green. Each show battery capacity that available. Where red shown rating $0-25 \%$, yellow $26-$ $50 \%$ and green $51-100 \%$.

$$
S o C=\frac{\operatorname{SOC}_{\operatorname{Section} A}+\operatorname{SOC}_{\text {Section } B}}{2}
$$

On manufacturing indicator battery program, SoC value from two section of battery was read and then calculated to find average using formula that has available don Equation 3. For read it be used read word SMBus protocol.

\section{Charging System}

In this case, be made charging system concept using CCCV methods. Where it was used LTC 4100. In the component has be equipped with SMBus to doing communication with other device. There are $\mathrm{I}_{\text {LIM }}$ and $\mathrm{V}_{\text {LIM }}$ pin that used to limit output current and voltage, using resistor between it with ground.

For circuit that has be made, not using resistor on the pin, so output maximum amount 4A and 27VDC. Made so, because current requirement to charge battery can achieve to $4 \mathrm{~A}$ with battery total capacity was $15 \mathrm{Ah}$, so the charging process can be processed approximately 3 hours. For voltage can be setting from $16-27 \mathrm{VDC}$, because design of battery was $15 \mathrm{VDC}$. Based on that setting, minimum power supply that can be used was $18 \mathrm{VDC}$ and $4 \mathrm{~A}$.

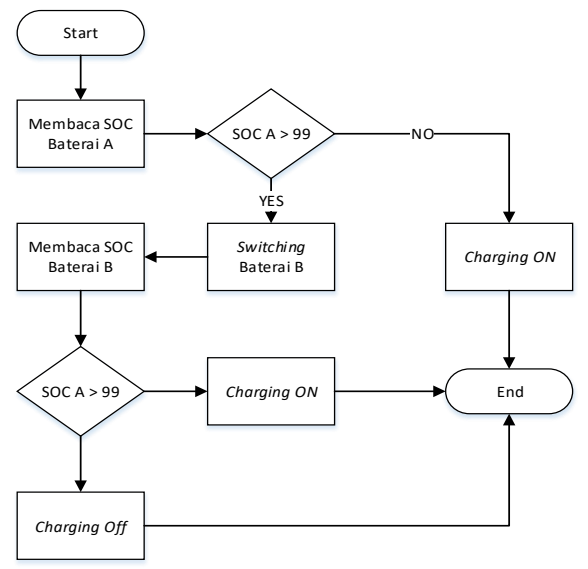

Figure 5. Charging System Flowchart.

On Figure 5 could be see that charging process was done on alternately between battery section A with section B. Used SoC parameter to determine where battery section will be charge. In the component that was used, could be setting output value of current and voltage using command conde chargingcurrent $(0 \times 14)$ and chargingvoltage (0x15). Data obtained from the command using $\mathrm{mV}$ and $\mathrm{mA}$ units. To begin charging process there was some requirement from component that it must be to fulfill. It was chargingvoltage() and chargingcurrent() must not worth zero. Then, input from adaptor must be connect, this case will be shown with comparing value DCDIV $>\mathrm{V}_{\mathrm{ACP}}$

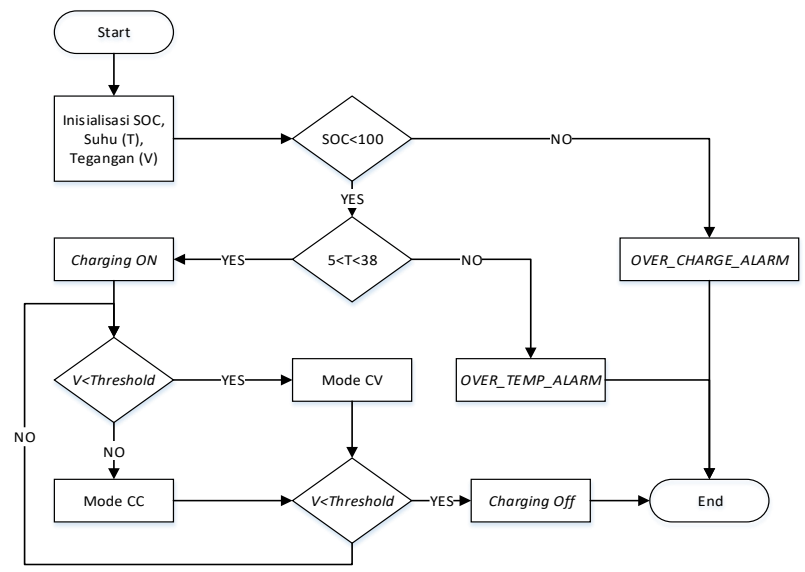

Figure 6. Charging Algorithm on Each Battery Section.

As shown in Figure 6, if battery voltage less than threshold voltage, so charging process done using constant current mode. If it's opposite, so charging process switch to constant voltage mode.

To prevent failure in charging process, on IC has equipped with protection form a function that can send signal and used to set charging process. In this case, host just sending the function in bit form, but not all inhibit charging process. Just over charged alarm, terminate charge alarm, reserve and over temp alarm bit that can inhibit charging process and setting alarm inhibited in function chargerstatur(). While, the other function doesn't have impact on LTC4100. For send it be used command code alarmwarning() (0x16).

Overcharge can be obtained with compare battery capacity value that it has charged with battery capacity design (in this case can be used SoC). When occur this condition at charging process, so host will be setting over charged alarm bit on charger. Over temperature can be obtained with read temperature battery and compare it with temperature that was permitted by battery. If the condition occur, so will be send over temp alarm bit.

\section{TESTING AND RESUlT}

\section{A. Output Powering System}

Pupose from this testing was to knowing noise value was produced from each output voltage regulator, where data that obtained has presented on Table 2. The value was affected by component layout, where supporting component must like capacitor, diode and inductor must be placed near with IC. VCC routing must be made keep of inductor, because induction that produced by the component has an impact on path in nearby. Then using component must have high accuration. Using capacitor with low ESR was very helpful to reduce noise value. 
TABLE 2.

OUTPUT VOLTAGE REgULATOR

\begin{tabular}{ccccc}
\hline \hline \multirow{2}{*}{ No } & \multirow{2}{*}{ Circuit } & \multicolumn{2}{c}{ Output $(\mathbf{V})$} & \multirow{2}{*}{ Vripple $(\mathbf{m V})$} \\
\cline { 3 - 4 } & $\mathbf{V}_{\text {MIN }}$ & $\mathbf{V}_{\text {MAX }}$ & \\
\hline 1 & Regulator 1 & 5.1 & 5.2 & 160 \\
2 & Regulator 2 & 4.8 & 5.0 & 160 \\
3 & Regulator 3 & 11.8 & 12.0 & 200 \\
4 & Regulator 4 & 11.8 & 12.0 & 200 \\
5 & Regulatro 5 & 12.0 & 12.2 & 200 \\
\hline \hline
\end{tabular}

\section{B. Powering System Efficient}

This data obtained with measuring output voltage and input current and output. From the data could be calculate how power input and output by calculating using formula in Equation 2.

$$
\text { Efisiensi }=\frac{P_{\text {out }}}{P_{\text {in }}} \times 100 \%
$$

TABLE 3.

EFFICIENT DATA

\begin{tabular}{cccc}
\hline $\begin{array}{c}\text { Power Input } \\
\text { (W) }\end{array}$ & Circuit & $\begin{array}{c}\text { Power Output } \\
\text { (W) }\end{array}$ & $\begin{array}{c}\text { Efficiency } \\
(\%)\end{array}$ \\
\hline 0.3 & Reg 1 & 0.1144864 & 38.16 \\
& Reg 2 & 0.0151906 & \\
0.93024 & Reg 3 & 0.1433986 & 49.21 \\
& Reg 4 & 0.1477398 & \\
\hline \hline
\end{tabular}

Through the data has displayed on Table 3 , could be calculate how long device can be operated. First step required was calculate input power. For input power on voltage regulator 1 can be seen on Equation 3 until 5 . Furthermore, for power input on system powering board can be seen on Equation 6 until 7. Then, calculate of power input total has presented on Equation 8 until 10.

$$
\begin{aligned}
& P_{\text {in }}=\frac{P_{\text {out }} \times 100}{\text { Efisiensi }} \\
& P_{\text {in }}=\frac{10 \times 100}{38.16} \\
& P_{\text {in }}=26.20 \mathrm{watt} \\
& P_{\text {in }}=\frac{10.212 \times 100}{49.21} \\
& P_{\text {in }}=20.75 \mathrm{watt} \\
& P_{\text {total }}=P_{\text {in regulator Ubec }}+P_{\text {in sistem powering }}+ \\
& P_{\text {ind.baterai }} \\
& P_{\text {total }}=26.20+52.24+2.5 \\
& P_{\text {total }}=47.45 \mathrm{watt}
\end{aligned}
$$

From total power that obtained could be calculate current requirement that the calculate has presented in Equation 11 until 13.

$$
\begin{aligned}
& I=\frac{P}{V} \\
& I=\frac{47.45}{15} \\
& I=3.16 \mathrm{~A}
\end{aligned}
$$

Then, could be calculate duration of use of tools, it has presented in Equation 14 until 19.

$t=\frac{I_{\text {Baterai }}}{I_{\text {Beban }}}$

$$
\begin{aligned}
& t=\frac{15}{3.16} \\
& t=4.74 \text { jam } \\
& t=4.74 \times 60 \\
& t=284.4 \text { menit } \\
& t=4: 44 \\
& \text { C. Data of SoC Battery }
\end{aligned}
$$

\section{Data of SoC Battery}

Data obtained from one section of battery and has be done randomly, where all condition was not obtained. All data that read on this test was displayed using serial monitor Arduino. Purpose from this test was to knowing how much difference SoC value with manual calculate of capacity using formula like on Equation 20.

$$
\text { Capacity }=\frac{\text { Remaining Capacity }}{\text { Design Capacity }} \times 100 \%
$$

TABLE 4. BATTERY SOC DATA

\begin{tabular}{cccccc}
\hline \hline No. & $\begin{array}{c}\text { SoC } \\
(\boldsymbol{\%})\end{array}$ & $\begin{array}{c}\text { Remaining } \\
\text { Capacity } \\
(\mathbf{m A h})\end{array}$ & $\begin{array}{c}\text { Design } \\
\text { Capacity } \\
(\mathbf{m A h})\end{array}$ & $\begin{array}{c}\text { Kapasitas } \\
\mathbf{( \% )}\end{array}$ & Difference \\
\hline 1 & 100 & 6800 & 6800 & 100 & 0 \\
2 & 90 & 6118 & 6800 & 89.97 & 0.03 \\
3 & 70 & 4749 & 6800 & 69.83 & 0.17 \\
4 & 60 & 4079 & 6800 & 59.98 & 0.02 \\
5 & 50 & 3392 & 6800 & 49.88 & 0.12 \\
6 & 40 & 2716 & 6800 & 39.94 & 0.06 \\
7 & 30 & 2029 & 6800 & 29.83 & 0.17 \\
8 & 20 & 1339 & 6800 & 19.69 & 0.31 \\
9 & 10 & 677 & 6800 & 9.95 & 0.05 \\
\hline \hline
\end{tabular}

From the data has displayed on Table 4, there can be seen difference between SoC value and manual calculate of capacity was less than 1 , so the SoC value application as battery indicator was no problem.

\section{Relation SoC with Voltage}

Purpose from this test was to knowing how voltage and SoC when battery was full and empty. From the data acquisition obtained when battery was full, the SoC value was $107 \%$ and voltage was 16.35 VDC. When battery was empty SoC value was $0 \%$ and voltage $11.9 \mathrm{VDC}$.

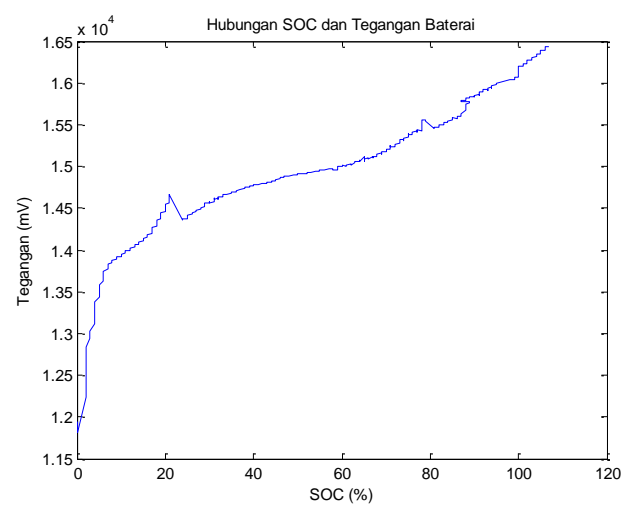

Figure 7. Relation SoC and Voltage.

\section{V.CONCLUSION}

Based on data that has been obtained from test and analysis, obtained noise value on powering system was 
International Conference on Engineering, Advance Science and Industrial Application (ICETESIA) 2018

September 6-7 2018, Institut Teknologi Sepuluh Nopember, Surabaya, Indonesia

$160 \mathrm{mV}$ for output $5 \mathrm{VDC}$ and $200 \mathrm{mV}$ for output $12 \mathrm{VDC}$. Furthermore, obtained efficiency value on voltage regulator 1 was $38.16 \%$ and on powering system board was $49.21 \%$. From the value, result of analysis show that device can be operated about 4 hours and 44 minutes. Battery voltage when full was 16.35VDC and at empty was 11.9VDC.

\section{REFERENCES}

[1] N. Checka, S. Schaffert, D. Demirdjian, J. Falkowski, and D. H. Grollman, "Handheld operator control unit," Proc. seventh Annu. ACM/IEEE Int. Conf. Human-Robot Interact. - HRI '12, p. 137, 2012.

[2] J. J. Zeng, R. Q. Yang, W. J. Zhang, X. H. Weng, and Q. Jun, "Research on semi-automatic bomb fetching for an EOD robot," Int. J. Adv. Robot. Syst., vol. 4, no. 2, pp. 247-252, 2007.

[3] F. Dastgeer, "Direct current distribution systems for residential areas powered by distributed generation," no. December, p. 4, 2011.

[4] B. T. Patterson, "DC Power Distribution System for Rural Applications," no. October, p. 2, 2012.

[5] C. Zhang, Y. Zheng, L. Li, X. Wang, and J. Yu, "Design and Simulation of EV Charging Device Based on Constant VoltageConstant Current PFC Double Closed-Loop Controller," no. Icaees, 2015.

[6] W. Wu, "Charging time estimation and study of charging behavior for automotive Li-ion battery cells using a Matlab / Simulink model," School of Electrical Engineering, 2016.

A. M. Inc, "Constant Current.".

L. about Electronics, "What is Constant Current Source?" . A. M. Inc, "Constant Voltage.".

S. E. Ltd, "Constant Voltage," 2014. .

M. Elias, A. Arof, and K. Nor, "Design of high energy lithiumion battery charger," Australas. Univ. Power Eng. Conf., no. September, 2004 